\title{
Reducing danger of heavy metals accumulation in winter wheat grain which is grown after leguminous perennial precursor
}

\author{
S. F. Razanov' ${ }^{1}$, O. P. Tkachuk $^{1}$, O. M. Bakhmat ${ }^{2}$, A. M. Razanova ${ }^{1}$ \\ ${ }^{1}$ Vinnytsia National Agrarian University, Vinnytsia, Ukraine \\ ${ }^{2}$ Podilskyi State Agrarian and Technical University, \\ Kamianets-Podilskyi, Ukraine
}

E-mail: tkachukop@ukr.net

Received: 14.02.2020 Accepted 10.03.2020

\begin{abstract}
Goal. Assessment of the influence of growing leguminous perennial herbs on the intensity of heavy metals accumulation in winter wheat as in a subsequent crop rotation. Methods. Field, laboratory atomic absorption method, mathematical and statistical processing. Results. cultivation of winter wheat after precursors of Medicago sativa I., Trifolium pratense L., Onobrychis arenaria Kit., Melilotus albus L., Lotus corniculatus L. or Galéga orientalis Lam. leads to a decrease in the content of lead by 1.8-2.5 times, cadmium - by 1.7-2.6 times, copper - 2.2-4.6 times and zinc - 1.6-1.9 times compared to winter wheat after corn precursor on silage. To obtain winter wheat with a minimum lead and copper content, the optimal precursor is Onobrychis arenaria Kit., with a minimum cadmium content - Galéga orientalis Lam. precursor, with a minimum copper and zinc content - the Trifolium precursorpratense $\mathrm{L}$. The lowest influence on the reduction of heavy metals accumulation in winter wheat grain is caused by the precursor Lotus corniculatus L. Thanks to the use of leguminous perennial herbs as a precursor to winter wheat, it is possible to reduce the accumulation coefficient of heavy metals by 1.1-2.9 times compared with the corn precursor on silage. The lowest accumulation coefficient of the studied heavy metals was observed after the precursor of Medicago sativa I. Conclusion. Leguminous perennial herbs - Medicago sativa I., Trifolium pratense L., Onobrychis arenaria Kit., Melilotus albus L., Lotus corniculatus L. and Galega orientalis Lam. promote optimization of soil condition by increasing the content of humus, minerals nutrients, optimization of soil acidity. As a result, they reduce the accumulation of heavy metals (lead, cadmium, copper, and zinc) in winter wheat as the next crop in crop rotation and contribute to the reduction of accumulation coefficient of heavy metals in winter wheat.
\end{abstract}

Key words: Heavy metals; Accumulation; Grain; Leguminous perennial herbs; Precursor

\section{Introduction}

Among the large number of toxicants which are entering the biosphere, a special place is occupied by heavy metals, which when they are entering the soil are included in the biogeochemical cycle and migrate the links of trophic chains into plants and their products (Xu et al., 2019, Gholizadeh et al., 2019). Heavy metals include chemical elements with a density greater than $5 \mathrm{~g} / \mathrm{cm}^{3}$, which have the properties of metals (Maschowski et al., 2019, Luo et al., 2019). Special attention among them is caused by Pb, Cd, $\mathrm{Zn}, \mathrm{Cu}$, which intensively enter the soil due to anthropogenic activity of the population (Ahmad et al., 2019, Lu et al., 2019).

Researches of many scientists in the world have found that phytotoxicity of heavy metals depends on such factors as: chemical properties (valence, ionic radius, ability to form complex compounds), soil and climatic conditions (physico-chemicalsoil properties, temperature, moisture) and specific features of plants and their resistance to pollution (Kashefighasemabadi et al., 2019).

Plants metabolize certain metals differently, for example, lead, even at high soil concentrations, is in poorly soluble compounds and therefore will be lower in the plant (Chuang et al., 2019). Zinc is highly accumulated and contained in plants; copper and cadmium are poorly stored and strongly retained (Kicinska et al., 2019; Li et al., 2019).

Lead and cadmium are toxic and hazardous chemicals that are mandatory for living organisms. Environmental pollution by these metals in some territories has reached critically dangerous levels, covering the entire biosphere, and has a negative impact on human health (Dong et al., 2019; Shao et al., 2019).

Pollution of farmland with heavy metals is mainly due to the atmospheric emissions of enterprises (Allevato et al., 2019), livestock farm waste and the use of fertilizers and pesticides (NurAini etal., 2019). Organic fertilizers also contain a significant amount of heavy metals. As a result of the introduction of organic matter into the soil, it increases the concentration of such chemical elements as lead, cadmium, copper, zinc, iron, manganese (Chen et al., 2019). Due to the intensive growth of mineral fertilizers used in recent years for growing crops in Ukraine by intensive farming technologies, the risk of heavy metals accumulation in crop production is growing. By penetrating plants, heavy metals adversely affect metabolism, which in the end leads to a decrease in yield and the risk of contamination by the toxicants of the following links in the food chain (Ugulu et al., 2019).

A considerable amount of research has been conducted in the world to study the mechanisms of cadmium and lead transfer from soil to plants (Wang et al., 2019). Lead is absorbed by plants mainly through the roots. Although the vegetative part of the plants 
slightly absorbs the compounds of lead, they are adsorbed on its surface and have a negative local effect, and when consumed by herbivorous animals - enter their body, causing a number of violations of it functioning. Unlike lead, cadmium is absorbed by plants both through the root system and through adsorption by the vegetative mass (Ravanbakhsh et al., 2019).

Removal of trace elements from agroecosystems is due to harvesting, leaching of soil, leaching, gas emission (Zheng et al., 2019; Liu et al., 2019). The removal of excess heavy metals from the soil is a long process that requires considerable material costs (Azogh et al., 2019; Lin et al., 2019). An alternative to chemical methods of soil purification from toxic concentrations of trace elements in recent years is cultivation on contaminated soil of plants with an increased need for particular trace elements (Sun et al., 2019; Guo et al., 2019.

The rate of transition of individual heavy metals into plant tissues varies significantly depending on their species (Romero-Estevez et al., 2019). Plants capable of accumulating heavy metals in large quantities can be used to biologically purify plants and reduce their accumulation in plants (Ventorino et al., 2019, Kumar et al., 2019).

Recently, many researchers have been focusing on elucidating the mechanisms of heavy metals uptake by plants in order to effectively clean them (Lei et al., 2019). This is an extremely pressing issue for Ukraine, especially for regions with high agricultural intensity and densely saturated industry levels. Therefore, the selection of effective absorber plants for such regions is of great scientific and practical importance.

A promising area of this is phytoremediation - a set of environmental technologies based on the use of plants and associated microorganisms to clean up areas polluted with heavy metals, radionuclides, pesticides and more. Phytoremediation technologies are intensively developing all over the world, while phytoremediation in Ukraine is at an early stage of development. Initially, phytoremediation was developed to eliminate soil pollution with heavy metals. Some plant species have been found not only able to withstand but also absorb and accumulate more ions of lead, mercury, zinc and other toxic metals than others. The technology under consideration is the natural process of biological circulation, which is part of the cultivation of accumulators, improvement of soil properties and their protection against erosion (Han et al., 2019, Kiran et al., 2019).

Phytoremediation has several advantages over physical remediation methods: it can be used in large areas, is much cheaper, does not require special equipment, contributes to the conservation and improvement of the environment, because it is associated withgrowing plants and improving soil condition (Kong et al., 2019).

Thus, the main tasks of phytoremediation at the present stage of science development are the selection of plantshyperaccumulators of heavy metals in order to remove them from polluted areas, to study the mechanism of action of phytoextractors (Zhou et al., 2019, Massadeh et al., 2019).

Prolonged use of high doses of fertilizers leads to the accumulation of ballast elements in the soil, which adversely affects its properties, fertility and quality of agricultural products. Research into the effects of heavy metals on crops has shown that an excessive amount of a number of trace elements (zinc, copper, manganese) can cause serious disturbances in plant growth and development. Some authors believe that the accumulation of heavy metals in the soil does not cause concern only to a certain level - as long as the plant can counteract heavy metals due to the protective mechanism of the root system. At the same time, cadmium, lead, mercury and copper belong to a critical group of substances that initiate environmental stress (Baghaie et al., 2019).

The results of researches of the influence of heavy metals on plants of Trifolium pratense L. have shown that the content of heavy metals in plant raw materials exceeds the maximum permissible concentrations, which indicates a high level of accumulation of metal ions. During the research period, the intensity of accumulation of $\mathrm{Zn}$ ions in plants decreases, and for Cu the biological absorption coefficient increases (Kour et al., 2019). This can be explained by the process of adaptation of Trifolium pratense $\mathrm{L}$. to growth conditions and, as a consequence, an increase in the level of biological resistance of plants to contamination. The property of Trifolium pratense $\mathrm{L}$. to accumulate heavy metals can be used as one of the methods of phytomonitoring and phytoremediation of the environment (Ivanova et al., 2019)

Considering the positive effect of growing leguminous perennial herbs on increasing soil fertility, it is possible to predict a decrease in the concentration of heavy metals in plants of subsequent crops in crop rotation after growing leguminous perennial herbs due to the increased accumulation in the tissues of leguminous perennial herbs of heavy metals and reduced their mobility due to the optimization of soil conditions by grasses

\section{Materials and Methods}

Field researches were conducted during 2013-2018 at the Agricultural Research Institute "Ahronomichne" of Vinnytsia National Agrarian University. The research field of "Ahronomichne" Research Center is located in the central part of the Vinnytsia region in the Central Forest Steppe and is located almost on the border of two geomorphological regions: the Letichev-Litin ancient alluvial basin and the water-glacial basinVinnytsia denudation-accumulative undulating plain of the Prydniprovska height.

The territory of the farm has a flat terrain characterized by a slight elevation and a weak division of the territory. The absolute altitudes reach $298 \mathrm{~m}$ above sea level. The height difference between the highest part of the watersheds and the decrease of the beams is $25-30 \mathrm{~m}$.

Field experimental area has a wide undulating relief, flat land dominated by slopes. The surface of the watershed plateau is leveled, its slope does not exceed $2-3^{\circ}$, so the surface run off of atmospheric and melt water is slow and the soil washout is almost absent. Soil moisture is due to precipitation, the groundwater level is at a depth of $10-15 \mathrm{~m}$.

According to agro-soil zoning, the experimental site belongs to the Vinnytsia-Nemyriv sub-district of the Central agro-soil district, almost on the border with the Khmelnytskyi-Pogrebyshchenskyi agro-soil district, the northern sub-province of the Forest-steppe right-bank.

Soil on the experimental site - grey podzolic ash-loam. The agrochemical composition of the soil of the reseach area is characterized by the following indicators: humus content $-2.0 \%$, hydrolyzed nitrogen (according to Kornfild) $-133 \mathrm{mg} / \mathrm{kg}$ soil - low, mobile forms of phosphorus (according to Chirikov) - $390 \mathrm{mg} / \mathrm{kg}$ soil - very high, mobile forms of potassium (according to Chirikov) - $64 \mathrm{mg} / \mathrm{kg}$ of soil - medium, calcium - $130 \mathrm{mg} / \mathrm{kg}$ of soil - sufficient, acidity hydrolytic - $2.53 \mathrm{mg}-\mathrm{eq} / 100 \mathrm{~g}$ of soil - increased, reaction of soil solution $\mathrm{pH}$ sol. 5,0 - medium acid. providing the site with trace elements: copper $-5.4 \mathrm{mg} / \mathrm{kg}$ soil, zinc $-6.0 \mathrm{mg} / \mathrm{kg}$ soil, heavy metal content: lead $-1.4 \mathrm{mg} / \mathrm{kg}$ soil, cadmium - not detected (Table 1 ). The researches were intended to study the effect of growing leguminous perennial herbs on changing the transition and accumulation of heavy metals in winter wheat. The following precursors of leguminous perennial herbs of winter wheat are studied: Medicago sativa L., Trifolium pratense L., Onobrychis arenaria Kit., Melilotus albus L., Lotus corniculatus L., Galega orientalis Lam., and control og corn for silage on environmental indicators of winter wheat grain content of lead $(\mathrm{Pb})$, cadmium $(\mathrm{Cd})$, copper ( $\mathrm{Cu})$ and zinc (Zn). Repeated field and laboratory 
experiments are four times. The accounting area of each variant is $50 \mathrm{~m}^{2}$, the total area of the plot is $70 \mathrm{~m}^{2}$. The variants in the experiment are systematically arranged in 7 blocks.

Table 1. Ecological and agrochemical parameters of soil of the experimental section of Ahronomichne Research Institute.

\begin{tabular}{llll}
\hline No & Indicator & Size & Rating \\
1 & Humus content, \% & 2,0 & low \\
2 & Nitrogen is hydrolyzed, $\mathrm{mg} / \mathrm{kg}$ soil & 133 & low \\
3 & Phosphorus mobile, $\mathrm{mg} / \mathrm{kg}$ soil & 390 & very high \\
4 & Mobile potassium, mg/kg & 64 & average \\
5 & Calcium, mg/kg soil & 130 & sufficient \\
6 & Acidity hydrolytic, mg-eq/100 g of soil & 2,53 & increased \\
7 & Soil solution reaction, $\mathrm{pHSol}$. & 5,0 & medium acid \\
8 & Copper mobile, mg/kg & 5,4 & $1,80 \mathrm{MPC}$ \\
9 & zinc mobile, mg/kg & 6,0 & $0,26 \mathrm{MPC}$ \\
10 & Lead mobile, mg/kg & 1,4 & $0,24 \mathrm{MPC}$ \\
11 & Cadmium mobile, $\mathrm{mg} / \mathrm{kg}$ & - & - \\
\hline
\end{tabular}

There were carried out the following observations, records and measurements. Determination of the content of heavy metals in winter wheat grains was carried out in certified and accredited laboratories: the Testing Center of Vinnytsia Branch of the State Institution "State soil protection" and the Scientific-Measuring Agrochemical Laboratory of the Departmentecology and environmental protection of Vinnytsia National Agrarian University. Grain samples were taken in accordance with the requirements of DSTU 4117: 2007. The determination of the pollution of heavy metals in the grain was carried out by atomic absorption method. Mathematical processing of researches results was carried out on the basis of statistical deviation of the average value of indicators from its extreme values.

The ethical standards of researches are: no copyright claims on the results of research by persons other than the authors of this scientific work; the author's team used their own funds to conduct field and laboratory studies; at Experimental work with agricultural plants was followed by biological standards.

\section{Results and Discussion}

The intensive use of fertilizers and pesticides on the soil under investigation in the previous years contributed to the accumulation of heavy metals in winter wheat grain and depended on the type of leguminous precursors

In particular, the lead content of winter wheat grown after corn for silage was $3.90 \mathrm{mg} / \mathrm{kg}$ cultivation of winter wheat after Lotus corniculatus L. contributed to a $42.8 \%$ reduction in lead content, $46.9 \%$ to Melilotus albus L., $52.3 \%$ to Medicago sativa I., to Galéga orientalis Lam. - by $53.1 \%$, Trifolium pratense L. - by $57.2 \%$ and after Onobrychis arenaria Kit. - by $59.5 \%$ less than after corn for silage (Table 2).

Table 2. Content of heavy metals in winter wheat depending on its precursors (Ahronomichne Research Institute, 2014-2018 average, $\mathrm{M} \pm \mathrm{m})$.

\begin{tabular}{lllll}
\hline Precursors & $\mathbf{P b}, \mathbf{~ m g} / \mathbf{k g}$ & $\mathbf{C d}, \mathbf{~ m g} / \mathbf{k g}$ & $\mathbf{C u} \mathbf{~ m g / k g}$ & $\mathbf{Z n , ~} \mathbf{m g} / \mathbf{k g}$ \\
Medicago sativa I. & $1,86 \pm 0,01$ & $0,16 \pm 0,002$ & $4,18 \pm 0,02$ & $24,84 \pm 0,03$ \\
Trifolium pratense L. & $1,67 \pm 0,01$ & $0,16 \pm 0,001$ & $3,88 \pm 0,02$ & $21,62 \pm 0,02$ \\
Onobrychis arenaria Kit. & $1,58 \pm 0,02$ & $0,17 \pm 0,001$ & $3,90 \pm 0,02$ & $22,16 \pm 0,01$ \\
Melilotus albus L. & $2,07 \pm 0,02$ & $0,17 \pm 0,001$ & $4,30 \pm 0,02$ & $24,22 \pm 0,01$ \\
Lotus corniculatus L. & $2,23 \pm 0,02$ & $0,20 \pm 0,002$ & $4,61 \pm 0,02$ & $22,56 \pm 0,01$ \\
Galega orientalis Lam. & $1,83 \pm 0,02$ & $0,13 \pm 0,002$ & $4,05 \pm 0,01$ & $25,24 \pm 0,01$ \\
Corn for silage & $3,90 \pm 0,02$ & $0,34 \pm 0,002$ & $9,91 \pm 0,02$ & $39,95 \pm 0,02$ \\
\hline
\end{tabular}

The lowest lead content in winter wheat grains was after the precursor of Onobrychis arenaria Kit. $-1.58 \mathrm{mg} / \mathrm{kg}$ after the precursor Trifolium pratense L. - 5.4\% more, Galéga orientalis Lam. - by $13.7 \%$, Medicago sativa I. - by $15.1 \%$, Melilotus albus L. - by $23.7 \%$ and after Lotus corniculatus L. - by $29.2 \%$.

The cadmium content of winter wheat grown after corn for silage was $0.34 \mathrm{mg} / \mathrm{kg}$. Cultivation of winter wheat after the precursor of Galéga orientalis Lam. made it possible to reduce cadmium content by $61.8 \%$, after Medicago sativa I. and Trifolium pratense L. by $53.0 \%$, Onobrychis arenaria Kit. and Melilotus albus L. - by $50.0 \%$ andafter Lotus corniculatus L. $-41.2 \%$ less than in winter wheat grown after corn for silage.

The lowest cadmium content in winter wheat grains was after the precursor Galéga orientalis Lam. $-0.13 \mathrm{mg} / \mathrm{kg}$ after the precursor of Medicago sativa I. and Trifolium pratense L. $-18.8 \%$ more after Onobrychis arenaria Kit. and Melilotus albus L. $-23.5 \%$ and after Lotus corniculatus L. $-35.0 \%$ more than after Galéga orientalis Lam.

Cultivation of winter wheat after corn for silage provides a copper content of grain of $9.91 \mathrm{mg} / \mathrm{kg}$. When growing wheat after the precursor of Trifolium pratense L., the copper content of the grain decreases by $60.9 \%$ after Onobrychis arenaria Kit. - by $60.7 \%$, Galéga orientalis Lam. By 59.1\%, Medicago sativa I. by $57.8 \%$, Melilotus albus L. By $56.6 \%$ and after Lotus corniculatus L. - 53.5\% less than after corn for silage.

The lowest copper content in winter wheat grains was found after the precursor Trifolium pratense L. $-3.88 \mathrm{mg} / \mathrm{kg}$. After the precursor of Onobrychis arenaria Kit. it was $0.5 \%$ higher after Galega orientalis Lam. - by $4.2 \%$, Medicago sativa I. - by $7.2 \%$, Melilotus albus L. - by $9.8 \%$ and after Lotus corniculatus L. - by $15.8 \%$ higher.

Cultivation of winter wheat after corn for silage allows to obtain a grain with a zinc content of $39.95 \mathrm{mg} / \mathrm{kg}$. When growing wheat after the precursor of Trifolium pratense L., the zinc content of the grain is reduced by $45.9 \%$, Onobrychis arenaria Kit. - by $44.5 \%$, Lotus corniculatus L. - by $43.5 \%$, Melilotus albus L. - by $39.4 \%$, Medicago sativa I. - by $37.8 \%$, and after Galega orientalis Lam. $36.8 \%$ less than after corn for silage. 
The lowest zinc content in winter wheat grains was found after the precursor Trifolium pratense $\mathrm{L}$. $-21.62 \mathrm{mg} / \mathrm{kg}$ after the precursor of Onobrychis arenaria Kit. - by $2.4 \%$ more, Lotus corniculatus L. - by $4.2 \%$, Melilotus albus L. - by $10.7 \%$, Medicago sativa I. - by $13.0 \%$ and after Galéga orientalis Lam. - 14,4\% more than after Trifolium pratense L.

The content of heavy metals in winter wheat grain is determined by the content of heavy metals in the soil, the coefficient of their accumulation, the content of humus, mobile phosphorus, the reaction of soil solution. In particular in the soil of Onobrychis arenaria Kit agrocenosis. the lowest content of mobile forms of lead $-1.5 \mathrm{mg} / \mathrm{kg}$, the highest content of humus, mobile forms of phosphorus, calcium, the highest index of reaction of soil solution of $\mathrm{pH}$ was observed, which facilitated the transfer of available onesin the soil of mobile forms of lead and copper in low-mobility compounds, and this led to the least accumulation in winter wheat of lead and copper. After the precursor of Galéga orientalis Lam. the soil had the highest soil solution of pH 7.2 and the lowest hydrolytic acidity, which resulted in the lowest content of winter wheat cadmium. After the Trifolium pratense $\mathrm{L}$. precursor, the highest soil pH solution and the lowest hydrolytic acidity were observed in the soil, which contributed to the smallest accumulation of winter wheat zinc and copper (Tables 3 and 4).

Table 3. Ecological and agrochemical parameters of soil depending on four-year growing of leguminous perennial herbs (NDG "Ahronomichne", 2013-2017, M \pm m).

\begin{tabular}{|c|c|c|c|c|c|c|c|}
\hline $\begin{array}{c}\text { Leguminous perennial } \\
\text { herbs }\end{array}$ & $\begin{array}{c}\text { Humus, } \\
\%\end{array}$ & $\begin{array}{c}\text { Hydro- } \\
\text { lyzed } \\
\text { nitrogen, } \\
\text { mg/kg } \\
\text { soil }\end{array}$ & $\begin{array}{c}\text { Contents } \\
\text { Movable } \\
\text { phos- } \\
\text { phorus, } \\
\text { mg/kg } \\
\text { soil }\end{array}$ & $\begin{array}{c}\text { Rolling } \\
\text { pota- } \\
\text { ssium, } \\
\text { mg/kg } \\
\text { soil }\end{array}$ & $\begin{array}{c}\text { Calcium, } \\
\mathbf{m g} / \mathbf{k g} \\
\text { soil }\end{array}$ & $\begin{array}{c}\text { Acidity is } \\
\text { hydrolytic, } \\
\text { mg- } \\
\text { eq } / \mathbf{1 0 0} \mathbf{~ g} \\
\text { soil }\end{array}$ & pH sol. \\
\hline Medicago sativa I. & $2,1 \pm 0,01$ & $137 \pm 1,41$ & $424 \pm 5,66$ & $86 \pm 4,24$ & $130 \pm 2,83$ & $0,40 \pm 0,014$ & $7,1 \pm 0,14$ \\
\hline Onobrychis arenaria Kit. & $2,3 \pm 0,07$ & $142 \pm 2,83$ & $444 \pm 5,66$ & $92 \pm 2,83$ & $133 \pm 4,24$ & $0,39 \pm 0,028$ & $7,2 \pm 0,28$ \\
\hline Lotus corniculatus L. & $2,1 \pm 0,14$ & $138 \pm 1,41$ & $430 \pm 2,83$ & $87 \pm 2,83$ & $134 \pm 2,83$ & $0,43 \pm 0,028$ & $7,0 \pm 0,28$ \\
\hline Galega orientalis Lam. & $2,2 \pm 0,07$ & $140 \pm 2,83$ & $435 \pm 5,66$ & $91 \pm 2,12$ & $133 \pm 2,83$ & $0,32 \pm 0,028$ & $7,2 \pm 0,14$ \\
\hline
\end{tabular}

Ecological safety of winter wheat grain is determined by the intensity of heavy metals accumulation in it. This is influenced by the content of heavy metals in the soil during the cultivation of winter wheat and the ratio of heavy metals from soil to grain.

The main indicator of the effectiveness of precursors in reducing the intensity of accumulation of heavy metals in the grain of crops is the coefficient of accumulation of heavy metals. This indicator is determined by the ratio of the content of heavy metals in the grain to the content of these toxicants in the soil. The lower the accumulation factor is the more effective the agro-environmental impact of its precursor.

The results of the researches showed that the highest rate of lead accumulation of winter wheat grain was observed as a precursor of corn for silage, which was 2.22. Cultivation of winter wheat after Medicago sativa I. reduced the rate of lead accumulation in its grain by $51.8 \%$, Trifolium pratense L. - by $46.9 \%$, Galéga orientalis Lam. - by $42.8 \%$, Melilotus albus L. - by $36.0 \%$, Onobrychis arenaria Kit. - by $35.6 \%$, Lotus corniculatus L. - by $18.0 \%$ compared to its precursor of corn for silage.

Table 4. Content of moving forms of heavy metals in soil depending on the cultivation of leguminous perennial herbs (Ahronomichne Research Institute, 2013-2017, M \pm m).

\begin{tabular}{|c|c|c|c|c|}
\hline \multirow{2}{*}{$\begin{array}{c}\text { Leguminous perennial } \\
\text { herbs }\end{array}$} & \multicolumn{4}{|c|}{ Content of mobile forms of heavy metals, $\mathbf{m g} / \mathbf{k g}$} \\
\hline & $\mathbf{P b}$ & Cd & $\mathbf{C u}$ & Zn \\
\hline Before growing herbs & $5,9 \pm 0,22$ & $0,60 \pm 0,08$ & $6,8 \pm 0,16$ & $9,1 \pm 0,08$ \\
\hline Medicago sativa $I$. & $3,6 \pm 0,19$ & $0,02 \pm 0,01$ & $0,1 \pm 0,01$ & $1,1 \pm 0,14$ \\
\hline Trifolium pratense $L$. & $3,0 \pm 0,22$ & $0,03 \pm 0,01$ & $6,7 \pm 0,22$ & $6,6 \pm 0,14$ \\
\hline Onobrychis arenaria Kit. & $1,5 \pm 0,07$ & $0,01 \pm 0$ & $0,4 \pm 0,08$ & $2,4 \pm 0,16$ \\
\hline Melilotus albus $L$. & $3,6 \pm 0,08$ & $0,60 \pm 0,01$ & $6,4 \pm 0,08$ & $4,3 \pm 0,08$ \\
\hline Lotus corniculatus L. & $3,4 \pm 0,08$ & $0,02 \pm 0,01$ & $0,2 \pm 0$ & $0,9 \pm 0,08$ \\
\hline Galega orientalis Lam. & $2,6 \pm 0,08$ & $0,01 \pm 0$ & $0,1 \pm 0$ & $1,1 \pm 0,14$ \\
\hline
\end{tabular}

The lowest winter wheat grain lead accumulation was found after Medicago sativa I. - 1.07. After Trifolium pratense L. - 9.3\% higher, Galéga orientalis Lam. - by $15.8 \%$, Melilotus albus L. - by $24.7 \%$, Onobrychis arenaria Kit. - by $25,2 \%$, Lotus corniculatus L. - by $41,2 \%$ higher and amounted to 1,82 (Table 5 ).

The cadmium accumulation coefficient of winter wheat grown after corn for silage was 2.13. Cultivation of winter wheat after Medicago sativa I. contributes to a $65.7 \%$ decrease in the cadmium grain accumulation by grain, to $60.1 \%$ by Trifolium pratense L., by Galéga orientalis Lam. - by $53.1 \%$, Melilotus albus L. - by $46.5 \%$, Onobrychis arenaria Kit. - on 20.2\%, Lotus corniculatus L. $14.6 \%$ less than after corn gor silage.

The lowest cadmium accumulation coefficient for winter wheat grain was 0.73 after Medicago sativa I., after Trifolium pratense L. $14.1 \%$ higher, Galéga orientalis Lam. - by $27.0 \%$, Melilotus albus L. - by $36.0 \%$, Onobrychis arenaria Kit. - by $57.1 \%$ Lotus corniculatus L. $-59.9 \%$ more than after Medicago sativa I., amounting to 1.82 . 
Table 5. Accumulation coefficient of heavy metals in winter wheat depending on its precursors (Ahronomichne Research Institute, 2014-2018 average, $M \pm m)$.

\begin{tabular}{lcccc}
\hline \multicolumn{1}{c}{ Precursor } & $\mathbf{P b}$ & $\mathbf{C d}$ & $\mathbf{C u}$ & $\mathbf{Z n}$ \\
Medicago sativa I. & $1,07 \pm 0,02$ & $0,73 \pm 0,01$ & $16,72 \pm 0,05$ & $23,66 \pm 0,16$ \\
Trifolium pratense L. & $1,18 \pm 0,01$ & $0,85 \pm 0,01$ & $19,40 \pm 0,26$ & $26,05 \pm 0,43$ \\
Onobrychis arenaria Kit. & $1,43 \pm 0,04$ & $1,70 \pm 0,13$ & $22,95 \pm 0,12$ & $34,63 \pm 0,27$ \\
Melilotus albus L. & $1,42 \pm 0,02$ & $1,14 \pm 0,01$ & $21,50 \pm 0,09$ & $28,17 \pm 0,16$ \\
Lotus corniculatus L. & $1,82 \pm 0,03$ & $1,82 \pm 0,03$ & $25,62 \pm 0,17$ & $34,71 \pm 0,75$ \\
Galega orientalis Lam. & $1,27 \pm 0,02$ & $1,00 \pm 0,01$ & $20,25 \pm 0,27$ & $31,16 \pm 0,76$ \\
Corn for silage & $2,22 \pm 0,01$ & $2,13 \pm 0,03$ & $29,15 \pm 0,21$ & $42,50 \pm 0,51$ \\
\hline
\end{tabular}

The copper accumulation coefficient of winter wheat after corn for silage was 29.15. Cultivation of winter wheat after Medicago sativa I. contributes to a $42.7 \%$ decrease in copper accumulation, to Trifolium pratense L. by $33.5 \%$, to Galéga orientalis Lam. - by $30.5 \%$, Melilotus albus L. - by $26.3 \%$, Onobrychis arenaria Kit. - by $21.3 \%$, Lotus corniculatus L. - $12,1 \%$ less than the coefficient of copper accumulation by grain after corn for silage. The lowest copper accumulation in winter wheat after Medicago sativa I. was 16.72 after Trifolium pratense L. - 13.8\% higher, Galéga orientalis Lam. - by 17,4\%, Melilotus albus L. - by 22,2\%, Onobrychis arenaria Kit. - by $27.2 \%$, Lotus corniculatus L. - by $34.7 \%$ higher than after Medicago sativa I. and amounted to 25.62.

The zinc accumulation coefficient of winter wheat grown after corn for silage was 42.50. Cultivation of winter wheat after Medicago sativa I. reduces the zinc accumulation rate by grain by $44.3 \%$, after Trifolium pratense L. - by $38.7 \%$ less, Melilotus albus L. - by $33.7 \%$, Galéga orientalis Lam. - by $26.7 \%$, Onobrychis arenaria Kit. - on $18.5 \%$ and after Lotus corniculatus L. - $18.3 \%$ less than after corn for silage. The lowest zinc accumulation factor of winter wheat grain was found after Medicago sativa I. - 23.66 after Trifolium pratense L. $-9.2 \%$ higher, Melilotus albus L. - $16.0 \%$, Galéga orientalis Lam. - by 24.1\%, Onobrychis arenaria Kit. - by $31.7 \%$ and after Lotus corniculatus L. - by $31.8 \%$ higher and amounted to 34.71 .

For all heavy metals, the lowest accumulation coefficient was observed after the precursor of Medicago sativa I. At the same time, in the soil of Agrocenosis Medicago sativa I., a high content of mobile forms of lead was observed $-5.7 \mathrm{mg} / \mathrm{kg}, \mathrm{copper}-6.8 \mathrm{mg} / \mathrm{kg}$ and zinc $-9.1 \mathrm{mg} / \mathrm{kg}$. It was found that in conditions of higher soil contamination with heavy metals, their content in plants increases, but the intensity of absorption of heavy metals from the soil decreases, which may be the result of the adaptive response of plants aimed atstabilization of mineral metabolism in conditions when the soil environment becomes unfavorable for plant growth. Also contributed to the decrease in the value of the heavy metal accumulation coefficient of winter wheat after Trifolium pratense $\mathrm{L}$. formation by its herbage of the highest soil reaction solution $\mathrm{pH}$ value and the lowest hydrolytic acidity. Soil, which led to the transfer of the moving forms of heavy metals from the soil to low-mobility compounds

The literature review indicates the possibility of using plants for phytoremediation of soils and improving the environmental safety of production of subsequent plants in rotation. Results of researches on the accumulation of heavy metals in winter wheat grains after various precursors have shown high phytoremediation ability of leguminous perennial herbs. Leguminous perennial herbs, as a precursor to winter wheat, contribute to a decrease in its lead grain by 1.8-2.5 times, cadmium - by 1.7-2.6 times, copper - by $2.2-$ 4.6 times and zinc - 1.6-1.9 times compared to traditional precursor corn for silage. The cultivation of winter wheat after Onobrychis arenaria Kit., compared to other leguminous precursors, contributes to the greatest reduction in its grain of lead and copper. After the precursor of Galéga orientalis Lam. cadmium content is most reduced in grain, but zinc accumulates. The cultivation of winter wheat after Trifolium pratense L. most significantly reduces the content of copper and zinc in its grain. After Lotus corniculatus L., the highest levels of lead, cadmium and copper are observed. At the same time, it should be noted that among all the precursors, the highest intensity of winter wheat grain contamination is observed after Lotus corniculatus $\mathrm{L}$.

Similar dependencies were found when growing plants of Trifolium pratense L. on soils with high copper and zinc content. Such features of Trifolium pratense L. have been transferred to other leguminous perennial herbs and revealed stronger positive manifestations of reducing the content of heavy metals in grains of subsequent crops in crop rotation, not only in copper and zinc content, but alsomore dangerous lead and cadmium.

Summarizing the results of researches to study the rate of accumulation of heavy metals with winter wheat grains after various precursors, it should be noted that winter wheat cultivation after Medicago sativa I. allows to provide the smallest lead, cadmium, copper and zinc accumulation coefficient; cultivation of winter wheat after Lotus corniculatus L. provides the highest accumulation of lead, cadmium, copper and zinc in the grain; cultivation of winter wheat after Onobrychis arenaria Kit. provides the highest zinc accumulation ratio in the grain; cultivation of winter wheat after the traditional precursor corn for silage, provides a higher rate of accumulation of all investigated heavy metals in grain than it growing after leguminous perennial herbs in 1.1-2.9 times. The heavy metal accumulation factor of winter wheat grain has shown that lead and cadmium are absorbed from the soil in small quantities, while the absorption of copper and zinc from the soil is significant, which defines these elements as important for growth and developmentwinter wheat plants.

\section{Conclusion}

Research results show that the decrease in the intensity of heavy metals accumulation in winter wheat grain is due to the optimization of the agro-ecological state of the soil after the cultivation of leguminous perennial herbs, which contributed to a significant reduction in the content heavy metals in grain. In particular, the lowest lead content in winter wheat grains was observed after the precursor of Onobrychis arenaria Kit. $-1.58 \mathrm{mg} / \mathrm{kg}$, cadmium after Galega orientalis Lam. - 0,13 mg/kg, copper and zinc after Trifolium pratense L. $-3,88$ and $21,62 \mathrm{mg} / \mathrm{kg}$ in accordance. This is determined by the lower content of mobile forms of heavy metals in the soil, the coefficient of their accumulation, the higher content of humus, mobile phosphorus, the optimal reaction of soil $\mathrm{pH}$ solution after these herbs. At the same time, the decrease in the intensity of the transition of heavy metals from soil to winter wheat plants was ensured by the formation of a physiological barrier to the plants, which limited the migration of toxicants from the soil with the highest content of heavy metals, which was observed on the variant of Medicago sativa L, in winter wheat plants. Because the lowest accumulation of lead, cadmium, copper and zinc in winter wheat grain was observed after the predecessor Medicago sativa L. and was 1.07 , respectively; $0.73 ; 16.72$ and 23.66. 


\section{References}

Xu Y.G., Qi F.J., Bai T.X., Yan Y.B., Wu C.C., An Z.R., Luo S., Huang Z., Xie P. (2019). A further inquiry into co-pyrolysis of straws with manures for heavy metal immobilization in manure-derived biochars. Journal of hazardous materials, 380. UNSP 120870. doi: 10.1016/j.jhazmat.2019.120870.

Gholizadeh A., Taghavi M., Moslem A., Neshat A.A., Najafi M.L., Alahabadi A., Ahmadi E., Aval H.E., Asouri A.A. Rezaei H. (2019). Ecological and health risk assessment of exposure to atmospheric heavy metals. Cotoxicology and environmental safety, 184. UNSP 109622. doi: 10.1016/j.ecoenv.2019.109622.

Maschowski C., Kruspan P., Garra P., Arif A.T., Trouve G., Giere R. (2019). Physicochemical and mineralogical characterization of biomass ash from different power plants in the Upper Rhine Region. FUEL, 258. UNSP 116020. doi: 10.1016/j.fuel.2019.116020.

Luo X., Ren B., Hursthouse A.S., Jiang F., Deng R. (2019). Potentially toxic elements (PTEs) in crops, soil, and water near Xiangtan manganese mine, China: potential risk to health in the foodchain. Environmental geochemistry and health, doi: 10.1007/s10653019-00454-9.

Ahmad I., Khan B., Asad N., Mian I.A., Jamil M. (2019). Traffic-related lead pollution in roadside soils and plants in Khyber Pakhtunkhwa, Pakistan: implications for human health. International journal of environmental science and technology, 16, 12, 80158022. doi: 10.1007/s13762-019-02216-7.

Lu Q.H., Xu Z., Xu X., Liu L., Liang L., Chen Z., Dong X., Li C., Wang Y., Qiu G. (2019). Cadmium contamination in a soil-rice system and the associated health risk: An addressing concern caused by barium mining. Ecotoxicology and environmental safety, 183. UNSP 109590. doi: 10.1016/j.ecoenv.2019.109590.

Kashefighasemabadi A., Karbassi A., Tabatabaee M., Dehabadi A.M. (2019). Development of soil pollution risk index in the vicinity of a waste dam in Chadormalu iron ore mine. International journal of environmental science and technology, 16, 12, 8485-8494. doi: 10.1007/s13762-019-02330-6.

Chuang M., Liu F.Y., Hu B., Wei M.B., Zhao J.H., Zhang K., Zhang H.Z. (2019). Direct evidence of lead contamination in wheat tissues from atmospheric deposition based on atmospheric deposition exposure contrast tests. Ecotoxicology and environmental safety, 185, UNSP 109688. doi: 10.1016/j.ecoenv.2019.109688.

Kicinska A. (2019). Environmental risk related to presence and mobility of As, Cd and TI in soils in the vicinity of a metallurgical plant - Long-term observations. Chemosphere, 236. UNSP 124308. doi: 10.1016/j.chemosphere.2019.07.039.

Li K., Cao C.L., Ma Y.B., Su D.C., Li J.M. (2019). Identification of cadmium bioaccumulation in rice (Oryza sativa L.) by the soil-plant transfer model and species sensitivity distribution. Science of the total environment, 692, 1022-1028. doi: 10.1016/j.scitotenv.2019.07.091.

Dong X.X., Yang F., Yang S.P., Yan C.Z. (2019). Subcellular distribution and tolerance of cadmium in Canna indica L. Ecotoxicology and environmental safety, 185, UNSP 109692. doi: 10.1016/j.ecoenv.2019.109692.

Shao Z.Q., Lu W.L., Nasar J., Zhang J.J., Yan L. (2019). Growth Responses and Accumulation Characteristics of Three Ornamentals Under Copper and Lead Contamination in a Hydroponic-Culture Experiment. Bulletin of environmental contamination and toxicology, 103, 6, 854-859. doi: 10.1007/s00128-019-02724-9.

Allevato E, Stazi SR, Marabottini R., D'Annibale A. (2019). Mechanisms of arsenic assimilation by plants and countermeasures to attenuate its accumulation in crops other than rice. Ecotoxicology and environmental safety, 185, UNSP 109701. doi: 10.1016/j.ecoenv.2019.109701.

NurAini A.B., Fauziah I.C. (2019). Effect of Triple Super Phosphate (TSP) and KH2PO4 at Different Application Rates on Biomass and Arsenic Uptake by Pteris vittata L. Malaysian journal of soil science, 23, 109-118.

Chen F., Zeng S.Y., Ma J., Li X.X., Zhang S.L., Zhu Q.L. (2019). Interactions between decabromodiphenyl ether and lead in soilplant system. Chemosphere, 236, UNSP 124406. doi: 10.1016/j.chemosphere.2019.124406.

Ugulu I., Unver M.C., Dogan Y. (2019). Potentially toxic metal accumulation and human health risk from consuming wild Urtica urens sold on the open markets of Izmir. Euro-mediterranean journal for environmental integration, 4, 1, UNSP 36 . doi: 10.1007/s41207-019-0128-7.

Wang M., Chen S.B., Chen L., Wang D., Zhao C.M. (2019). The responses of a soil bacterial community under saline stress are associated with $\mathrm{Cd}$ availability in long-term wastewater-irrigated field soil. Chemosphere, 236, UNSP 124372. doi: 10.1016/j. chemosphere.2019.124372.

Wang, C.Y., Wu B.D., Jiang K., Wei M., Wang S. (2019). Effects of different concentrations and types of Cu and Pb on soil N-fixing bacterial communities in the wheat rhizosphere. Applied soil ecology, 144, 51-59. doi: 10.1016/j.apsoil.2019.07.008.

Ravanbakhsh M., Kowalchuk G.A., Jousset A. (2019). Optimization of plant hormonal balance by microorganisms prevents plant heavy metal accumulation. Journal of hazardous materials, 379, UNSP 120787. doi: 10.1016/j.jhazmat.2019.120787.

Zheng H., Wang M., Chen S., Li S., Lei X.Q. (2019). Sulfur application modifies cadmium availability and transfer in the soil-rice system under unstable pe plus pH conditions. Ecotoxicology and environmental safety, 184, UNSP 109641. doi: 10.1016/j.ecoenv.2019.109641.

Liu J., Hou H., Zhao L., Sun Z., Lu Y., Li H. (2019). Mitigation of Cd accumulation in rice from Cd-contaminated paddy soil by foliar dressing of $S$ and $P$. Science of the total environment, 690, 321-328. doi: 10.1016/j.scitotenv.2019.06.332.

Azogh A., Marashi S.K., Babaeinejad T. (2019). Effect of zeolite on absorption and distribution of heavy metal concentrations in roots and shoots of wheat under soil contaminated with weapons. Toxin reviews, doi: 10.1080/15569543.2019.1684949.

Lin J., He F., Su B., Sun M., Owens G., Chen Z. (2019). The stabilizing mechanism of cadmium in contaminated soil using green synthesized iron oxide nanoparticles under long-term incubation. Journal of hazardous materials, 379. UNSP 120832. doi: 10.1016/j.jhazmat.2019.120832.

Sun G.L., Reynolds E.E., Belcher A.M. (2019). Designing yeast as plant-like hyperaccumulators for heavy metals. Nature communications, 10, 5080. doi: 10.1038/s41467-019-13093-6.

Guo Y., Qiu C., Long S., Wang H., Wang Y. (2019). Cadmium accumulation, translocation, and assessment of eighteen Linum usitatissimum L. cultivars growing in heavy metal contaminated soil. International journal of phytoremediation, doi: 10.1080/15226514. 2019.1683714.

Romero-Estevez D., Yanez-Jacome G.S., Simbana-Farinango K., Navarrete H. (2019). Content and the relationship between cadmium, nickel, and lead concentrations in Ecuadorian cocoa beans from nine provinces. Food control, 106. UNSP 106750. doi: 10.1016/j.foodcont.2019.106750. 
Ventorino V., Pascale A., Fagnano M., Adamo P., Faraco V., Rocco C., Fiorentino N., Pepe O. (2019). Soil tillage and compost amendment promote bioremediation and biofertility of polluted area. Journal of cleaner production, 239. UNSP 118087. doi: 10.1016/j.jclepro.2019.118087.

Kumar V., Thakur R.K., Kumar P. (2019). Assessment of heavy metals uptake by cauliflower (Brassica oleracea var. botrytis) grown in integrated industrial effluent irrigated soils: A prediction modeling study. Scientia horticulturae, 257.108682. doi: 10.1016/j.scienta.2019.108682.

Lei M., Pan Y.Q., Chen C.Y., Du H.H., Tie B.Q., Yan X.P., Huang R.Z. (2019). Application of economic plant for remediation of cadmium contaminated soils: Three mulberry (Moms alba L.) varieties cultivated in two polluted fields. Chemosphere, 236. UNSP 124379. doi: 10.1016/j.chemosphere.2019.124379.

Carrion C.S., Mendoza W.J. (2019). Potential Phytoremediator of Native Species in Soils Contaminated by Heavy Metals in the Garbage Dump Quitasol-Imponeda Abancay. Journal of sustainable development of energy water and environment systemsjsdewes, 7, 4, 584-600. doi: 10.13044/j.sdewes.d7.0261.

Chaturvedi R., Favas P.J.C., Pratas J., Varun M., Paul M.S. (2019). Metal (loid) induced toxicity and defense mechanisms in Spinacia oleracea L.: Ecological hazard and Prospects for phytoremediation. Ecotoxicology and environmental safety, 183. Unsp 109570. doi: 10.1016/j.ecoenv.2019.109570.

Bielecka A., Krolak E. (2019). Selected Features of Canadian Goldenrod That Predispose the Plant to Phytoremediation. Journal of ecological engineering, 20, 10, 88-93. doi: 10.12911/22998993/112906/.

Han R., Dai H.P., Zhan J., Wei S.H. (2019). Clean extracts from accumulator efficiently improved Solanum nigrum L. accumulating $\mathrm{Cd}$ and $\mathrm{Pb}$ in soil. Journal of cleaner production, 239. UNSP 118055. doi: 10.1016/j.jclepro.2019.118055.

Kiran B.R., Prasad M.N. (2019). Biochar and rice husk ash assisted phytoremediation potentials of Ricinus communis L. for leadspiked soils. Ecotoxicology and environmental safety, 183. UNSP 10957. doi: 10.1016/j.ecoenv.2019.109574.

Kong Z.Y., Wu Z.J., Glick B.R., He S.Y., Huang C., Wu L. (2019). Co-occurrence patterns of microbial communities affected by inoculants of plant growth-promoting bacteria during phytoremediation of heavy metal contaminated soils. Ecotoxicology and environmental safety, 183. UNSP 109504. doi: 10.1016/j.ecoenv.2019.109504.

Zhou W., Zhang J., Zou M., Liu X., Di X., Wang Q., Liu Y., Liu Y., Li J. (2019). Feasibility of Using Rice Leaves Hyperspectral Data to Estimate $\mathrm{CaCl}_{2}$-extractable Concentrations of Heavy Metals in Agricultural Soil. Scientific reports, 9, 16084. doi: 10.1038/s41598019-52503-z.

Massadeh A.M., Massadeh S.A. (2019). Removal of $\mathrm{Cu}$ and $\mathrm{Zn}$ from Aqueous Solutions by Selected Tree Leaves with Phytoremediation Potential. Water air and soil pollution, 230, 11, 264. doi: 10.1007/s11270-019-4323-6.

Baghaie A.H., Fereydoni M. (2019). The potential risk of heavy metals on human health due to the daily consumption of vegetables. Environmental health engineering and management journal, 6, 1, 11-16. doi: 10.15171/EHEM.2019.02.

Kour R., Jain D., Bhojiya A.A., Sukhwal A., Sanadhya S., Saheewala H., Jat G., Singh A., Mohanty S.R. (2019). Zinc biosorption, biochemical and molecular characterization of plant growth-promoting zinc-tolerant bacteria. Biotech, 9, 11, 421. doi: 10.1007/s13205-019-1959-2.

Ivanova L.P., Detcheva A.K., Vassileva P.S. (2019). Characterization of Two Bulgarian Herbs for Use as Biosorbents for Copper (II). Analytical letters, 52, 17, 2650-2662. doi: 10.1080/00032719.2019.1587447.

\section{Citation:}

Razanov, S.F. Tkachuk, O.P., Bakhmat, O.M., Razanova A.M. (2020). Reducing danger of heavy metals accumulation in winter wheat grain which is grown after leguminous perennial precursor. Ukrainian Journal of Ecology, 10(1), 254-260.

\begin{tabular}{|l|l}
\hline$(c))_{\mathrm{EY}}$ \\
\hline
\end{tabular} 